\title{
The Impact of China's Foreign Exchange Reserves on Currency Mismatch
}

\author{
Ronghua Chen ${ }^{1,2}$ \\ 1 Hohai University, Nanjing, China; \\ 2 Jianghai Polytechnic College, Yangzhou, China \\ crh321@hotmail.com;gong197509@163.com
}

\begin{abstract}
At present, China is facing very serious currency mismatch, and this has brought about some negative impacts on China's economic development and financial stability. This paper makes an empirical study of the impact of foreign exchange reserves on currency mismatch. The results of the study show that foreign exchange reserves have a significant and persistent effect on currency mismatch. Finally, based on the findings of the study and the current situation of China's foreign exchange reserves, this paper proposes some countermeasures.
\end{abstract}

Keywords- currency mismatch central bank foreign exchange reserves

\section{I.INTRODUCTION}

Currency mismatch,which refers to the use of different currency, is essentially exchange rate risk. When exchange rate fluctuates its related assets or liabilities, income or expenditure are affected. On the one hand, the increase of China's foreign exchange reserves leads to foreign currency assets increase, and the assets are far more than the external debt, which in turn directly leads to the increase of currency mismatch. On the other hand, with the increase of China's foreign exchange reserves, the management of the currency structure and maturity structure in foreign exchange reserves is more difficult, which also increases the risk of currency mismatch.

So, with the increase of foreign exchange reserves, China is facing serious currency mismatch. Based on this understanding, an empirical study about the impact of foreign exchange reserves on currency mismatch is made and some solutions are proposed in this paper.

\section{THE NEGATIVE IMPACT ON CURRENCY MISMATCH IN CHINA}

In recent years, China's net foreign currency assets is too much and its structure is unreasonable. This makes China face serious currency mismatch and has brought about some negative impacts, as could be seen in the following:

\section{A The high cost of ownership}

First, the central bank has huge foreign currency assets, but can not invest in domestic projects that can generate higher returns, thus resulting in a high opportunity cost; second, when U.S. dollar's purchasing power declines or U.S. dollar devalue relative to other reserve currency, China will face a huge net foreign currency assets depreciation loss; third, with China's main foreign currency assets invested in U.S. Treasury and agency debt, Chinese interest rate financing through the international market is much more than the U.S. national debt interest rate. As a result, China suffers the loss of interest.

$B$ The impact on the central bank's monetary policy and exchange rate policy

First, the huge net foreign currency assets and the expanding trade surplus make many countries think that $\mathrm{RMB}$ is undervalued, thus giving China international pressure. If RMB does not appreciate, China will face international trade friction and even trade sanctions. If RMB appreciates, it will have a very negative impact on Chinese many low-tech traditional industries. Therefore, the central bank is in a dilemma; Second, the direction of China's exchange rate system reform is floating exchange rate system, but severe currency mismatch affects China's floating exchange rate system reform. If RMB appreciates, the domestic economy, especially exports be seriously affected. If RMB devalues, it will increase the external debt burden. So the central bank has to maintain exchange rate fluctuations within a narrow range; Third, currency mismatch affects money supply. The result of China's holding a huge amount of net foreign assets is that the central bank puts in a large amount of base money. Because of its multiplier effect, the money supply doubles.

\section{THE EMPIRICAL ANALYSIS ABOUT THE IMPACT OF FOREIGN EXCHANGE RESERVES ON CURRENCY MISMATCH}

This paper selects the balance of annual foreign exchange reserves as the foreign exchange reserves data (FER). Scholars have proposed a number of indicators to measure currency mismatch, such as, original sin index, net foreign currency asset or liability, foreign exchange risk exposure, AECM indicator. Goldstein and Turner proposed AECM indicator in 2004 and AECM indicator is used to measure the degree of currency mismatch. Compared with other indicators, AECM indicator is more applicable to China's current status of currency mismatch. Therefore, this paper selects AECM indicator as the measure indicator of currency mismatch. As this paper does not study the measure of currency mismatch, it does not calculate China's AECM indicator, but uses other scholar's result. The results of different scholars are different. Comparing these different results, this paper selects the result of Xiyang 
Huang and Zhaoben Fang (2009).

Generally speaking, most of the time series are not stationary, so first stationarity test is necessary for each variable, and then the cointegration test is done to test long-term stable relationship between foreign exchange reserves and currency mismatch, and finally, this paper uses impulse response function analysis to analyze the dynamic impact of foreign exchange reserves on currency mismatch. In addition, in order to eliminate heteroscedasticity of the series, before the empirical analysis, the series are handled by calculating natural logarithm.

\section{A Stationarity Test}

using $\mathrm{ADF}$ to test the stationary of the series, the results are shown in Table 1.

Table 1: ADF test results of each sequence

\begin{tabular}{|l|l|l|l|l|}
\hline Variable & LnFER & $\triangle$ LnFER & LnAECM & $\triangle$ LnAECM \\
\hline ADF & -2.32004 & -3.65589 & -2.80147 & -2.64669 \\
\hline Threshold & $-3.2964^{\text {* }}$ & $-3.0521^{\text {* }}$ & $-3.2856^{\text {* }}$ * & $-2.6672^{\text {* }}$ \\
\hline AIC & -0.46457 & -0.29526 & -0.41214 & 0.01386 \\
\hline SC & -0.21952 & -0.14822 & -0.21428 & 0.16090 \\
\hline $\begin{array}{l}\text { Type } \\
\text { (C,T,M })\end{array}$ & $(\mathrm{C}, \mathrm{T}, 2)$ & $(\mathrm{C}, 0,1)$ & $(\mathrm{C}, \mathrm{T}, 1)$ & $(\mathrm{C}, 0,1)$ \\
\hline results & Nonstationary & stationary & Nonstationary & stationary \\
\hline
\end{tabular}

Note: (1) ${ }^{*}$, * ${ }^{*}$ represent the significance level of $5 \%$ and $10 \%$ respectively; (2) In (C, T, M), C represents the constant, $\mathrm{T}$ stands for the trend, $\mathrm{M}$ stands for the lag. Where $\mathrm{C}$ and $\mathrm{T}$ are selected based on sequence features, $\mathrm{M}$ is selected based on the minimum of AIC and SC.

According to the results of ADF test, the series are non-stationary, and their first difference are significant in the significance level of $5 \%$ or $10 \%$, This indicates that all variables are first-order integrated series, and can begin cointegration analysis.

\section{B Cointegration Test}

We begin the cointegration test for LnAECM and LnFER, using the EG two-step method

Using the least squares method, after several attempts, we obtain the following regression equation:

\section{$\operatorname{LnAECM}_{\mathrm{t}}=0.3578 \mathrm{LnFER}_{\mathrm{t}} \quad(\mathrm{AR}(1)=0.706)$}

$\mathrm{R}^{2}=0.874, \mathrm{~A}-\mathrm{R}^{2}=0.867, \mathrm{DW}=2.01, \mathrm{t}$ value of regression coefficient is 13.026. Looking at the results of the regression, $\mathrm{R}^{2}$ shows a very high degree of fitting equation. By introducing $\mathrm{AR}(1)$ reduces the problem of residual autocorrelation. Regression coefficient is significant in the significance level of $1 \%$. the overall effect of the model is good.

Supposing $\mathrm{E}_{\mathrm{t}}=\mathrm{LnAECM}_{\mathrm{t}}-0.3578 \mathrm{LnFER}_{\mathrm{t}}$

A stationarity test is done for $E_{t}$, and test results show that $E_{t}$ is a stationary series, so cointegration relationship exists between LnAECM and LnFER.

C The Impulse Response Analysis
The cointegration analysis shows that foreign exchange reserves and currency mismatch in China have long-term stable relationship. The following uses the impulse response function analysis to analyze the impact of foreign exchange reserves on currency mismatch. The response of currency mismatch to the shocks of foreign exchange reserves is shown as following.

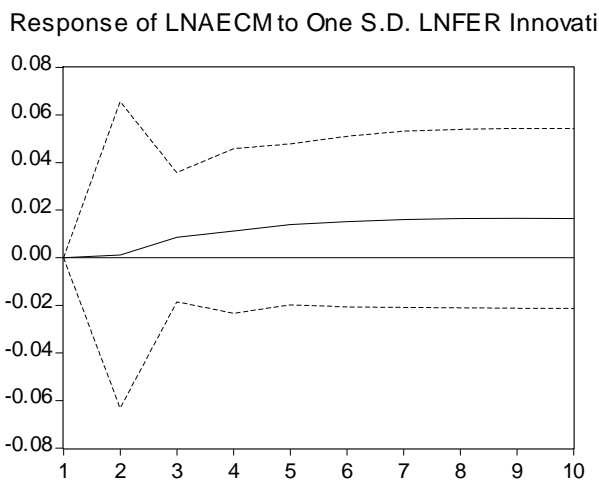

It can be seen from the above figure that a shock to the foreign exchange reserves, the response of currency mismatch is positive, indicating that the increase of foreign exchange reserves leads to the increase of currency mismatch. It can also be seen that the response of currency mismatch increases slowly from the second period, in the seventh period to reach the maximum and maintain the maximum. Such a trend suggests that the positive responses have tended to stabilize, this shows that the impact of the foreign exchange reserves on currency mismatch is persistent.

\section{COUNTERMEASURES}

The present empirical analysis shows that China's foreign exchange reserves have significant impact on currency mismatch, and this effect is persistent. In order to reduce currency mismatch, the central bank need to optimize the scale management and the structure management of foreign exchange reserves.

\section{A Optimizing the scale management of foreign exchange reserves}

1) Reducing the "Twin Surplus".

The main source of foreign exchange reserves is "twin surplus", that is, the current account surplus and capital account surplus. Therefore, appropriate reduction of the current account surplus and capital account surplus is an effective means for reducing foreign exchange reserves. In order to effectively reduce the "twin surplus", China can proceed as following:

a) To increase domestic consumption. In the troika of " consumption, investment and exports", consumption is serious shortage in China, not only below the level of developed countries, but also significantly lower than the world average level, which leads to the high dependence of economy on foreign trade (exports). Foreign trade has 
become an important power of economic growth, but foreign trade has led to the rapid development of China's trade surplus for years, thus increasing China's foreign exchange reserves. In order to fundamentally solve the trade imbalance and effectively to reduce the trade surplus, China must increase domestic consumption.

b) The implementation of "going out" strategy. With the increase in direct foreign investment, foreign investment is far more than China's overseas investment, resulting in a sustained surplus of China's capital account. Therefore, speeding up the implementation of "going out" strategy to increase overseas investment, is necessary for reducing the capital account surplus.

c) To strengthen the management of hot money. Because of the expected appreciation of RMB and China's rapid economic development, a large number of hot money are pouring into China. Therefore, strengthening the management of hot money, is also an important means of reducing foreign exchange reserves.

2) Reforming of Mandatory Foreign Exchange

Settlement System.

In 1994 foreign exchange system was reformed, and the mandatory foreign exchange settlement system was implemented. Since then, the growth of foreign exchange reserves has accelerated markedly and mandatory foreign exchange settlement system has become the direct institutional factors for foreign exchange reserve growth. Therefore, the reform of mandatory foreign exchange settlement system, such as permitting businesses and individuals holding certain foreign exchange, can effectively reduce the central bank's foreign exchange reserves.

\section{$B$ Optimizing the structure management of foreign exchange reserves}

1) Optimizing the currency structure of foreign exchange reserves

The currency structure refers to ratio of various currency reserve assets in foreign exchange reserves. In China's foreign exchange reserves, U.S. assets account for the most, and the proportion of yen, euro, pound assets is small. With such a structure, U.S. dollar depreciation will have a strong influence on the security of China's foreign exchange reserves, and increase the risk of currency mismatch. Therefore, optimizing the currency structure of China's foreign exchange reserves is necessary, that is, diversified holdings of reserve currency assets.

a) The appropriate reduction of U.S. dollar assets in China's foreign exchange reserves. U.S. dollar is the world's most important currency and it should account for the largest share of China's foreign exchange reserves, but in China's foreign exchange reserves U.S. dollar assets is more than $70 \%$ and exceeds reasonable level, so reducing U.S. dollar assets is necessary. The general view is that U.S. dollar assets is not more than $50 \%$.

b) The appropriate increase of euro assets in China's foreign exchange reserves. The ratio of euro assets in China's foreign exchange reserves is very low, which is incompatible with the status of euro in the international monetary system. The appropriate increase of euro assets, both agrees with the status of euro in the international monetary system and conforms to China's economic ties with the euro, and also reduces the risk of currency mismatch.

c) Strengthening dynamic management of currency structure. In order to reduce the risk of currency mismatch, according to the change of the international foreign exchange market, China should timely adjust the currency structure of foreign exchange reserves to minimize the impact

2) Optimizing the maturity structure of foreign exchange reserves

China should adjust its maturity structure of foreign exchange reserves according to the maturity structure of external debt, and make the maturity structure of foreign exchange reserves match the maturity structure of external debt, which can reduce the impact of exchange rate fluctuation to external debt and foreign exchange reserves. In addition, China should adjust its maturity structure of foreign exchange reserves based on changes of market conditions to reduce the impact of exchange rate fluctuation on foreign exchange reserves.

\section{REFERENCES}

[1]. Shaobo Liu and Qingchun He. Chinese currency mismatch level and its influencing factors. Management World, 2007(3)pp32-41

[2]. Xiyang Huang and Zhaoben Fang. Currency mismatch: theoretical analysis, empirical testing with China's choice. Research on Financial and Economic Issues, 2009(9)pp66-70

[3].Suqin Wang. Currency mismatch of developing countries and effectiveness of monetary policy. Jianhan Forum , 2008(6)pp58-61

[4]. Russell Green, Tom Torgerson. Are high foreign exchange reserves in emerging markets a blessing or a burden?. Occasional Paper No.6, March 2007.

[5]Marc-Andre Gosselin, Nicolas Parent. An empirical analysis of foreign exchange reserves in emerging Asia. Bank of Canada working Paper 2005-38, December 2005.

[6] Robert N McCauley, Ben S C Fung. Choosing instruments in managing dollar foreign exchange reserves.BIS Quarterly Review, March 2003pp39-46 